\title{
Variation Orders in Building Projects in Khartoum State-Sudan: The Causes and the Impact on Projects Performance
}

\author{
Eltahir Elshaikh \\ schoolcivil@yahoo.com \\ Construction Engineering Department, Sudan University of Science and Technology, Khartoum, Sudan \\ Salma Mahmoud \\ salmaymm@gmail.com \\ Civil Engineering Department, University of Science and Technology, Khartoum, Sudan
}

\begin{abstract}
Occurrence of variation orders (VOs) is a common phenomenon in building projects and a challenging feature. Opinions and feedback of the stakeholders of building projects at Khartoum State - Sudan were investigated to identify and rank the key factors that cause VOs and evaluate their consequent impact on projects' performance. 10 projects were thoroughly analyzed to determine how their performance was affected by the occurrence of VOs and in conjunction with this an industry wide survey that was conducted to determine the frequency of occurrence of a previously compiled list of factors. 130 respondents -contractors, consultants, projects' owners and project managers-took part in the survey. Considering the frequency of occurrence and the strength of their impact, the relative importance index from the participants' feedback was calculated allowing the ranking of the factors causing VOs. It was found that the main causes for VOs emerged from the owners' side and are mainly attributed to changing his needs or scope of work. It was also confirmed that there is a significant relationship between the occurrence of VOs and projects' time extension (by 22-200\%) and cost overrun (by 2.67-42.86).
\end{abstract}

Keywords: Variation orders; Khartoum; Sudan; Building projects

\section{INTRODUCTION}

The building industry is one of the largest industries in the world. Sudan, as one of the developing countries, put some efforts to commit a reasonable share of their annual budgets for the building sector. With best efforts to execute the projects as planned for, the occurrence of VOs is still a common feature and a recurring phenomenon in most if not all building projects stakeholders in Khartoum State Sudan. VOs depict any deviation from the agreed upon (scope, time, cost or quality) among the project's stakeholders (Osman et al, 2010). Concerns and some preliminary, informal investigations with some construction managers in Sudan, revealed that VOs are viewed as a major source of nuisance leading to contract over budget and time extension problems. Consequently, this study was launched to investigate the root causes of VOs in building projects in Khartoum State- Sudan as viewed from the perspective of all the stakeholders and to evaluate their impact on some selected project performance dimensions.

\section{PREVIOUS STUDIES}

Previous studies that considered the same phenomenon but in their own settings were 
consulted. That made it possible to compile a list of factors, which are highlighted as causes of VOs in construction projects. A study in Gaza Strip described 64 factors among which "lack of materials and equipment spare parts, design change by consultant, lack of consultant's experience, design errors and omission, conflicts between contract documents, owner's financial problems, lack of coordination among project parties, and change is specification by owners" were the most significant (Enshassi et al., 2010). With a similar study geared towards the investigation of VOs in highway projects, $(\mathrm{Wu}$ et al., 2005) differentiated between external and internal causes where he considered the external causes to include factors such as political, economic, natural environmental aspects and third party. On the other hand, he classified the internal causes as those initiated by the owner, construction design consultant, contractor or other parties.

Studies on VOs in Oman, as described by (Alnuaimi et al., 2010) confirmed that clients' additional works or design modifications come at the top of the list of frequently occurring and most influential factors while adding the unavailability of formal construction manuals and procedures besides some quality related issues as other causes. With a proven adverse impact on project s' performance, VOs effect on productivity and project costs was reported by (Cox, 1997) who viewed then as unwanted but inevitable source for cost escalation, time overrun and declining quality.

\section{MATERIALS AND METHODS}

To tackle the stated problem and allow measuring the stakeholders' opinions regarding the raised concerns, both qualitative and quantitative approaches were adopted.

\subsection{Preliminary Investigation}

In the preliminary stage, an in-depth investigation was conducted through the study of 10 building projects developed and executed at the State of Khartoum, Sudan during a range of 8 years covering the period (2007-2015). For each project the contract documents and progress reports were reviewed to provide a clear explanation of the actual deviations that took place and allow spotting the causes and the probable impact on the overall project performance. After defining and meticulously tracking the VOs occurred, the projects' participants were interviewed to give an account on what they think the actual causes and hence the possible consequences as happening within their context.

\subsection{Industry Survey}

The preliminary investigation was followed by an industry-wide survey to validate the preliminary outcomes from the studied cases and to allow generalizing the results. A questionnaire form was designed, tested and translated then devised as a tool to collect the required data. Part of the questionnaire included a close-ended question comprising 28 factors, previously highlighted in the literature and the studied cases, as the main causes of VOs. Depending on their experience, respondents were asked to state the frequency of occurrence of each of the listed factors against a 5-points Likert scale. Another question was devised to measure the possible impact of VOs on the project performance as viewed by the project participants. The participants responded by weighting the impact on cost and time and the weighted average for their feedback was determined. 


\subsubsection{Sample Size and Configuration}

The survey participants were client, civil engineering contractors, consultants and project managers and were randomly selected from the official reference lists of the Sudanese Contractors Union and the Council of Organizations of Consultants in Sudan. The sample size was determined on the basis of statistical principles for this type of exploratory research following equations (1) and (2) as described in the literature for this type of research (Yin, 2009; Palinkas et al., 2015):

$$
\begin{aligned}
& n_{0}=\left(P^{*} q\right) / V^{2} \\
& n=n_{0} /\left[1+\left(n_{0} / N\right)\right]
\end{aligned}
$$

Where:

$n_{0}$ : first estimate of sample size,

$P$ : the proportion of the characteristic being measured in the target population,

$q$ : complement of ' $p$ ' or $1-p$,

$V$ : maximum standard error allowed,

$N$ : population size,

$n$ : sample size.

180 responses were targeted from the four major groups who represent the projects' stakeholders. 130 respondents successfully participated in the survey. Table 1 portrays the sample configuration and the response rate.

Table 1: Survey Sample Configuration

\begin{tabular}{|c|c|c|c|}
\hline \multirow{2}{*}{ Respondents category } & \multicolumn{3}{|c|}{ Questionnaire } \\
\cline { 2 - 4 } & Copies distributed & Copies returned & Response rate (\%) \\
\hline Clients & 35 & 23 & 65.71 \\
\hline Contractors & 70 & 53 & 75.71 \\
\hline Consultants & 60 & 47 & 78.33 \\
\hline Project managers & 15 & 7 & 46.67 \\
\hline Total & 180 & 130 & 72.2 \\
\hline
\end{tabular}

\subsubsection{Data Analysis}

The Statistical Package for Social Sciences (SPSS) version 21.0. was used for the analysis of the obtained data where the reliability test was performed to measure the degree to which a research instrument (questionnaire) yields consistent results or data after repeated trials. A commonly accepted rule of thumb for describing internal consistency using Cronbach's alpha as described in the literature by (Kombo \& Tromp, 2006) is as stated in Table 2.

Table 2: Cronbach's alpha consistency rule

\begin{tabular}{|c|c|}
\hline Cronbach's Coefficient Alpha & Internal Consistency Remarks \\
\hline$\alpha \geq 0.9$ & Excellent \\
\hline $0.7 \leq \alpha<0.9$ & Good \\
\hline $0.6 \leq \alpha<0.7$ & Acceptable \\
\hline $0.5 \leq \alpha<0.6$ & Poor \\
\hline$\alpha<0.5$ & Unacceptable \\
\hline
\end{tabular}


The Cronbach's alpha coefficient value for the questionnaire was 0.857 . This value according to table 2 , indicates that the questionnaire items form a scale that has good internal consistency that could be used as a reliable data collection tool. 2017)

(RII) was calculated according to equation (3) as described in (Mohammed et al,

$$
R I I=(5 \times 5+4 \times 4+3 \times 3+2 \times 2+x 1)(5 * N)
$$

Where:

$\mathrm{X}_{\mathrm{i}}$ : the number of respondents who selected the option of impact;

$\mathrm{N}$ : the total number of respondents.

\section{RESULTS ANALYSIS AND DISCUSSION}

\subsection{Preliminary results}

Table 3 shows the results that emerged from the studied cases. The calculations of the percentage increase in cost and time due to VOs were presented. It is evident for the investigated projects that a substantial majority (75\%) of the recorded causes for VOs were related to the owner's changing needs, scope of work, change of materials prices of in local market, changing government regulations and legislation and change in the project use. I was also found that a direct relationship exists between the presence of VOs and the project's time increase. It was noticed that the projects' durations were extended by (22-200) \% due to VOs while the cost analysis exercise showed over budget expenses to increase by $(2.67-42.86) \%$ due to VOs.

Table 3: Variation orders and their impact on projects' cost and time

\begin{tabular}{|c|c|c|c|c|c|c|c|}
\hline \multirow[b]{3}{*}{$\begin{array}{l}\text { Studies } \\
\text { Projects }\end{array}$} & \multirow[b]{3}{*}{$\begin{array}{c}\text { Causes of Occurrence of Variation } \\
\text { Orders }\end{array}$} & \multicolumn{6}{|c|}{ Impact of VOs on the Project Dimensions } \\
\hline & & \multicolumn{3}{|c|}{ Cost } & \multicolumn{3}{|c|}{ Time } \\
\hline & & $\begin{array}{c}\text { Initial } \\
\text { Contract } \\
\text { Cost } \\
\text { (Million } \\
\text { SDG) }\end{array}$ & $\begin{array}{c}\text { Final } \\
\text { Contract } \\
\text { Cost } \\
\text { (Million } \\
\text { SDG) }\end{array}$ & $\begin{array}{l}\% \text { of } \\
\text { Increase in } \\
\text { the contract } \\
\text { cost }\end{array}$ & $\begin{array}{l}\text { Initial } \\
\text { Project } \\
\text { Duration } \\
\text { (Month) }\end{array}$ & $\begin{array}{c}\text { Final } \\
\text { Project } \\
\text { Duration } \\
\text { (Month) }\end{array}$ & $\begin{array}{c}\% \text { of } \\
\text { Increase } \\
\text { in the } \\
\text { project } \\
\text { duration }\end{array}$ \\
\hline Project (1) & $\begin{array}{l}\text { - } \quad \text { Change use of building } \\
\text { - } \quad \text { Design Changes, } \\
\text { - Instability of prices }\end{array}$ & 140 & 200 & 42.86 & 24 & 42 & 75 \\
\hline Project (2) & $\begin{array}{l}\text { - } \quad \text { Client's changing needs } \\
\text { - } \quad \text { Instability of prices }\end{array}$ & 6 , & 7.5 & 25 & 12 & 16 & 33 \\
\hline Project (3) & $\begin{array}{l}\text { - } \quad \text { Client's changing needs } \\
\text { Design Changes }\end{array}$ & 8 & 8.42 & 5.25 & 18 & 22 & 22 \\
\hline Project (4) & $\begin{array}{l}\text { - } \quad \text { Client's changing needs } \\
\text { Design Changes }\end{array}$ & 2.5 & 2.85 & 14 & 12 & 21 & 75 \\
\hline Project (5) & $\begin{array}{ll}\text { - } & \text { Changing government } \\
\text { regulations and legislation }\end{array}$ & 4 & 5 & 25 & 9 & 27 & 200 \\
\hline Project (6) & $\begin{array}{l}\text { - Client's changing needs } \\
\text { - } \quad \text { Change use of building } \\
\text { - Design Changes }\end{array}$ & 22 & $22 . .91$ & 4.14 & 20 & 35 & 75 \\
\hline Project (7) & $\begin{array}{l}\text { - } \quad \text { Client's changing needs } \\
\text { - } \quad \text { Change use of building } \\
\quad \text { Design Changes }\end{array}$ & $17 . .5$ & 19.9 & 13.71 & 12 & 18 & 50 \\
\hline Project (8) & $\begin{array}{l}\text { - } \quad \text { Client's changing needs } \\
\text { Design Changes }\end{array}$ & 140 & 161 & 15 & 18 & 54 & 200 \\
\hline Project (9) & $\begin{array}{l}\text { - } \quad \text { Client's changing needs } \\
\quad \text { Design Changes }\end{array}$ & 6 & 6.16 & 2.67 & 18 & 30 & 66.67 \\
\hline Project (10) & $\begin{array}{l}\text { Change the Scope of Work } \\
\text { - Design Changes }\end{array}$ & 30 & 32 & 6.67 & 12 & 22 & 83 \\
\hline
\end{tabular}




\subsection{Industry Survey Results}

\subsubsection{Frequency of occurrence of the factors causing VOs}

Based on the assertion that VOs could be caused by several factors with a variable impact levels, the weighted averages for respondents' opinions made it possible to rank the factors depending on the frequency of their occurrence as depicted in table 4.

The results showed that the most frequently occurring factors causing VOs are:(1) Lack of stability of prices and the exchange rate change, (2) New government regulations, (3) Non availability of construction manual and procedure for construction project in Sudan, (4) Errors and omissions in design ,two factors in the same ranking (5) Owner fails to make decisions or review document at the right time and Owner's needs during the design stage are not well-defined or variably, (7) Owner's financial problems ,two factors in the same ranking (8) Contractors financial difficulties and The lack of coordination between consultant and contractors and subcontractors and (10) Non-use value engineering in design stage to find the best alternatives and providing cost.

Table 4: Factors causing VOs and their impact on cost and time

\begin{tabular}{|c|c|c|c|c|c|c|c|}
\hline Factor & Factor Description & Very Often & Often & Sometimes & Seldom & Never & \begin{tabular}{|c|} 
Relative Importance \\
Index \\
\end{tabular} \\
\hline \multirow{2}{*}{ F 1} & \multirow{2}{*}{ Owner's financial problems } & 74 & 33 & 15 & 3 & 5 & 0.86 \\
\hline & & $56.92 \%$ & $25.38 \%$ & $11.54 \%$ & $2.31 \%$ & $3.85 \%$ & \\
\hline \multirow{2}{*}{ F 2} & \multirow{2}{*}{ Change of plan by Owner } & 75 & 20 & 25 & 9 & 1 & 0.84 \\
\hline & & $57.69 \%$ & $15.38 \%$ & $19.23 \%$ & $6.92 \%$ & $0.77 \%$ & \\
\hline \multirow{2}{*}{ F 3} & \multirow{2}{*}{ Change of Scope by Owner } & 72 & 28 & 21 & 6 & 3 & 0.85 \\
\hline & & $55.38 \%$ & $21.54 \%$ & $16.15 \%$ & $4.62 \%$ & $2.31 \%$ & \\
\hline \multirow{2}{*}{ F 4} & \multirow{2}{*}{$\begin{array}{l}\text { Owner fails to maintain hold on the } \\
\text { project schedule. }\end{array}$} & 69 & 21 & 24 & 12 & 4 & 0.81 \\
\hline & & $53.08 \%$ & $16.15 \%$ & $18.46 \%$ & $9.23 \%$ & $3.08 \%$ & \\
\hline \multirow{2}{*}{ F 5} & \multirow{2}{*}{$\begin{array}{l}\text { Owner fails to make decisions or } \\
\text { review document at the right time. }\end{array}$} & 85 & 24 & 15 & 4 & 2 & 0.89 \\
\hline & & $65.38 \%$ & $18.46 \%$ & $11.54 \%$ & $3.08 \%$ & $1.54 \%$ & \\
\hline \multirow[b]{2}{*}{ F 6} & \multirow{2}{*}{$\begin{array}{l}\text { Owner's needs during the design } \\
\text { stage are not well-defined or } \\
\text { variably. }\end{array}$} & 87 & 21 & 15 & 5 & 2 & 0.89 \\
\hline & & $66.92 \%$ & $16.15 \%$ & $11.54 \%$ & $3.85 \%$ & $1.54 \%$ & \\
\hline \multirow[b]{2}{*}{ F 7} & \multirow{2}{*}{$\begin{array}{l}\text { Change in design by engineer or } \\
\text { consultant }\end{array}$} & 64 & 27 & 25 & 8 & 6 & 0.81 \\
\hline & & $49.23 \%$ & $20.77 \%$ & $19.23 \%$ & $6.15 \%$ & $4.62 \%$ & \\
\hline \multirow[b]{2}{*}{ F 8} & \multirow[b]{2}{*}{ Conflict between contract documents } & 81 & 19 & 14 & 8 & 8 & 0.84 \\
\hline & & $62.31 \%$ & $14.62 \%$ & $10.77 \%$ & $6.15 \%$ & $6.15 \%$ & \\
\hline \multirow{2}{*}{ F 9} & \multirow{2}{*}{ Errors and omissions in design } & 90 & 22 & 9 & 4 & 5 & 0.89 \\
\hline & & $69.23 \%$ & $16.92 \%$ & $6.92 \%$ & $3.08 \%$ & $3.85 \%$ & \\
\hline \multirow[b]{2}{*}{ F 10} & \multirow{2}{*}{$\begin{array}{l}\text { The scope of work for the contractor } \\
\text { is not well defined }\end{array}$} & 80 & 16 & 20 & 7 & 7 & 0.84 \\
\hline & & $61.54 \%$ & $12.31 \%$ & $15.38 \%$ & $5.38 \%$ & $5.38 \%$ & \\
\hline \multirow{2}{*}{ F 11} & \multirow{2}{*}{ Technology changes } & 72 & 26 & 16 & 7 & 9 & 0.82 \\
\hline & & $55.38 \%$ & $20.00 \%$ & $12.31 \%$ & $5.38 \%$ & $6.92 \%$ & \\
\hline \multirow[b]{2}{*}{ F 12} & \multirow{2}{*}{$\begin{array}{l}\text { The lack of coordination between } \\
\text { consultant and contractors and } \\
\text { subcontractors }\end{array}$} & 84 & 17 & 18 & 3 & 8 & 0.86 \\
\hline & & $64.62 \%$ & $13.08 \%$ & $13.85 \%$ & $2.31 \%$ & $6.15 \%$ & \\
\hline \multirow{2}{*}{ F 13} & \multirow{2}{*}{ Differing site conditions } & 76 & 17 & 19 & 5 & 13 & 0.81 \\
\hline & & $58.46 \%$ & $13.08 \%$ & $14.62 \%$ & $3.85 \%$ & $10.00 \%$ & \\
\hline \multirow{2}{*}{ F 14} & & 82 & 21 & 15 & 6 & 6 & 0.86 \\
\hline & Contractors financial difficulties & $63.08 \%$ & $16.15 \%$ & $11.54 \%$ & $4.62 \%$ & $4.62 \%$ & \\
\hline & The required labor skill are not & 76 & 23 & 17 & 12 & 2 & 0.84 \\
\hline F 15 & available & $58.46 \%$ & $17.69 \%$ & $13.08 \%$ & $9.23 \%$ & $1.54 \%$ & \\
\hline & The required equipment and tools & 72 & 23 & 17 & 11 & 7 & 0.82 \\
\hline F 16 & are not available & $55.38 \%$ & $17.69 \%$ & $13.08 \%$ & $8.46 \%$ & $5.38 \%$ & \\
\hline & Material not meeting the & 72 & 17 & 14 & 9 & 18 & 0.78 \\
\hline F 17 & specifications & $55.38 \%$ & $13.08 \%$ & $10.77 \%$ & $6.92 \%$ & $13.85 \%$ & \\
\hline & Contractor desire to improve his & 72 & 19 & 13 & 8 & 18 & 0.78 \\
\hline F 18 & financial conditions & $55.38 \%$ & $14.62 \%$ & $10.00 \%$ & $6.15 \%$ & $13.85 \%$ & \\
\hline
\end{tabular}




\begin{tabular}{|c|c|c|c|c|c|c|c|}
\hline \multirow{2}{*}{ F 19} & \multirow{2}{*}{$\begin{array}{l}\text { construction delay by other } \\
\text { contractors working on different } \\
\text { contracts }\end{array}$} & 80 & 21 & 11 & 15 & 3 & 0.85 \\
\hline & & $61.54 \%$ & $16.15 \%$ & $8.46 \%$ & $11.54 \%$ & $2.31 \%$ & \\
\hline \multirow{2}{*}{ F 20} & \multirow{2}{*}{$\begin{array}{l}\text { Acceleration of work Safety } \\
\text { consideration / emergency field } \\
\text { conditions }\end{array}$} & 67 & 26 & 14 & 15 & 8 & 0.80 \\
\hline & & $51.54 \%$ & $20.00 \%$ & $10.77 \%$ & $11.54 \%$ & $6.15 \%$ & \\
\hline \multirow{2}{*}{ F 21} & \multirow{2}{*}{ Weather conditions } & 70 & 16 & 18 & 17 & 9 & 0.79 \\
\hline & & $53.85 \%$ & $12.31 \%$ & $13.85 \%$ & $13.08 \%$ & $6.92 \%$ & \\
\hline \multirow{2}{*}{ F 22} & \multirow{2}{*}{ Demolition and re-work } & 60 & 22 & 14 & 13 & 21 & 0.73 \\
\hline & & $46.15 \%$ & $16.92 \%$ & $10.77 \%$ & $10.00 \%$ & $16.15 \%$ & \\
\hline \multirow{2}{*}{ F 23} & \multirow{2}{*}{$\begin{array}{l}\text { Difference between the design and } \\
\text { the actual construction on site }\end{array}$} & 76 & 13 & 16 & 9 & 16 & 0.79 \\
\hline & & $58.46 \%$ & $10.00 \%$ & $12.31 \%$ & $6.92 \%$ & $12.31 \%$ & \\
\hline \multirow{2}{*}{ F 24} & \multirow{2}{*}{ New government regulations } & 99 & 19 & 8 & 4 & 0 & 0.93 \\
\hline & & $76.15 \%$ & $14.62 \%$ & $6.15 \%$ & $3.08 \%$ & $0.00 \%$ & \\
\hline \multirow{2}{*}{ F 25} & \multirow{2}{*}{$\begin{array}{l}\text { Lack of stability of prices and the } \\
\text { exchange rate change }\end{array}$} & 107 & 17 & 3 & 3 & 0 & 0.95 \\
\hline & & $82.31 \%$ & $13.08 \%$ & $2.31 \%$ & $2.31 \%$ & $0.00 \%$ & \\
\hline \multirow{2}{*}{ F 26} & \multirow{2}{*}{$\begin{array}{l}\text { Non-use value engineering in design } \\
\text { stage to find the best alternatives and } \\
\text { providing cost }\end{array}$} & 86 & 14 & 14 & 11 & 5 & 0.85 \\
\hline & & $66.15 \%$ & $10.77 \%$ & $10.77 \%$ & $8.46 \%$ & $3.85 \%$ & \\
\hline \multirow{2}{*}{ F 27} & \multirow{2}{*}{$\begin{array}{l}\text { Non availability of construction } \\
\text { manual and procedure for } \\
\text { construction project in Sudan }\end{array}$} & 97 & 16 & 10 & 3 & 4 & 0.91 \\
\hline & & $74.62 \%$ & $12.31 \%$ & $7.69 \%$ & $2.31 \%$ & $3.08 \%$ & \\
\hline \multirow{2}{*}{ F 28} & \multirow{2}{*}{$\begin{array}{l}\text { Obstinate nature of owner and } \\
\text { consultant }\end{array}$} & 60 & 17 & 10 & 19 & 24 & 0.71 \\
\hline & & $46.15 \%$ & $13.08 \%$ & $7.69 \%$ & $14.62 \%$ & $18.46 \%$ & \\
\hline
\end{tabular}

\subsubsection{Impact of VOs on projects' time and cost performance}

With a variable impact level, respondents were asked to give their opinion to help gauging the impact of VOs on projects' performance. The results obtained are as presented in Table 5.

Table 5 shows the respondents' feedback summary on weighting the impact of VOs on projects' performance. That included workers decreased productivity, (2) Increase the cost of the projects, (3) Delay in completion schedule, (4) Disputes between owners and contractor, (5) Decrease in quality of work, (6) Increase in overhead expenses, (7) Increase in duration of individual activities, (8) Demolition and re - work, (9) Delay in payments (10) Hold on work in other areas, (11) Additional money for contractor.

Table 5: Impact of VOs on projects cost and time performance

\begin{tabular}{|c|c|c|c|c|c|c|}
\hline Impact & very Often & Often & Sometimes & Seldom & Never & $\begin{array}{c}\text { Relative } \\
\text { Importance } \\
\text { Index }\end{array}$ \\
\hline \multirow{2}{*}{$\begin{array}{l}\text { Increase the cost of } \\
\text { the projects }\end{array}$} & 89 & 30 & 11 & 0 & 0 & 0.92 \\
\hline & $68.46 \%$ & $23.08 \%$ & $8.46 \%$ & $0.00 \%$ & $0.00 \%$ & \\
\hline \multirow{2}{*}{$\begin{array}{l}\text { Increase in duration } \\
\text { of individual } \\
\text { activities }\end{array}$} & 68 & 33 & 13 & 13 & 3 & 0.83 \\
\hline & $52.31 \%$ & $25.38 \%$ & $10.00 \%$ & $10.00 \%$ & $2.31 \%$ & \\
\hline \multirow{2}{*}{$\begin{array}{l}\text { Delay in completion } \\
\text { schedule }\end{array}$} & 94 & 17 & 9 & 7 & 3 & 0.90 \\
\hline & $72.31 \%$ & $13.08 \%$ & $6.92 \%$ & $5.38 \%$ & $2.31 \%$ & \\
\hline \multirow{2}{*}{ Delay in payments } & 75 & 18 & 14 & 13 & 10 & 0.81 \\
\hline & $57.69 \%$ & $13.85 \%$ & $10.77 \%$ & $10.00 \%$ & $7.69 \%$ & \\
\hline \multirow{2}{*}{$\begin{array}{l}\text { Demolition and re - } \\
\text { work }\end{array}$} & 78 & 15 & 16 & 15 & 6 & 0.82 \\
\hline & $60.00 \%$ & $11.54 \%$ & $12.31 \%$ & $11.54 \%$ & $4.62 \%$ & \\
\hline
\end{tabular}




\begin{tabular}{|l|c|c|c|c|c|c|}
\hline \multirow{2}{*}{$\begin{array}{l}\text { Decrease in } \\
\text { productivity of } \\
\text { workers }\end{array}$} & 97 & 19 & 11 & 3 & 0 & 0.92 \\
\cline { 2 - 7 } & $74.62 \%$ & $14.62 \%$ & $8.46 \%$ & $2.31 \%$ & $0.00 \%$ & \\
\hline \multirow{2}{*}{$\begin{array}{l}\text { Increase in overhead } \\
\text { expenses }\end{array}$} & 82 & 21 & 7 & 15 & 5 & 0.85 \\
\cline { 2 - 7 } & $63.08 \%$ & $16.15 \%$ & $5.38 \%$ & $11.54 \%$ & $3.85 \%$ & \\
\hline \multirow{2}{*}{$\begin{array}{l}\text { Decrease in quality } \\
\text { of work }\end{array}$} & 91 & 18 & 7 & 6 & 8 & 0.87 \\
\cline { 2 - 7 } & $70.00 \%$ & $13.85 \%$ & $5.38 \%$ & $4.62 \%$ & $6.15 \%$ & 0 \\
\hline $\begin{array}{l}\text { Disputes between } \\
\text { owners and } \\
\text { contractor }\end{array}$ & 91 & 15 & 12 & 12 & 0 & 0.88 \\
\hline \multirow{2}{*}{$\begin{array}{l}\text { Hold on work in } \\
\text { other areas }\end{array}$} & $60.00 \%$ & $11.54 \%$ & $9.23 \%$ & $9.23 \%$ & $0.00 \%$ & \\
\hline & $52.31 \%$ & $11.54 \%$ & $14.62 \%$ & $9.23 \%$ & $12.31 \%$ & \\
\hline \multirow{2}{*}{$\begin{array}{l}\text { Additional money for } \\
\text { contractor }\end{array}$} & 66 & 13 & 13 & 17 & 21 & 0.76 \\
\cline { 2 - 7 } & $50.77 \%$ & $10.00 \%$ & $10.00 \%$ & $13.08 \%$ & $16.15 \%$ & \\
\hline
\end{tabular}

\section{CONCLUSION}

The results obtained from this study displayed the major factors causing VOs, confirmed that they emerged from the owners' side, and are mainly attributed to changing his needs or scope of work. It was also confirmed that there is a significant relationship between the occurrence of VOs and projects' time extension (by 22-200\%) and cost overrun (by 2.67-42.86).

\section{REFERENCES}

Alnuaimi, S. A., Taha, A. R., Al Mohsin, M. \& Al-Harthi, S. A. (2010) Causes, Effects, Benefits, and Remedies of Change Orders on Public Construction Projects in Oman. Journal of Construction Engineering and Management, Vol. 136, No. 5.

Arun, C. \& Rao, B. N. (2007). Knowledge based decision support tool for duration and cost overrun analysis of highway construction projects. J. Inst. Eng. (India), Part AG, Vol. 88, pp. 27-33.

Cox, R. K. (1997). Managing change orders and claims. Journal of Management in Engineering, ASCE, Vol. 13, No. 1, pp. 24-30.

Enshassi, A., Arain, F. \& AlRaee, S. (2010) Causes of variation orders in construction projects in the Gaza Strip. Journal of Civil Engineering and Management, 16(4), pp. 540-551.

George, D. \& Marllery, P. (2003). SPSS for Windows Step by Step: A Simple Guide and Reference.

Kombo, D. K. \& Tromp, D. L. A. (2006). (Proposals and Thesis Writing: An Introduction). Nairobi: Pauline's Publications Africa.

Mohammed, E. E., Mohammed, S. Y. \& Hassan, A. S. (2017). Factors causing variation orders in building projects in Khartoum State-Sudan. International Journal of Engineering Sciences \& Research Technology, 6(11), 117-129.

Mizanur, R. M. D., Dai, L. Y. \& Khanh, H. D. (2014). Investigating main causes for schedule delay in construction projects in Bangladesh. Journal of Construction Engineering and Project Management, 4(3), 33-46.

Osman, Z., Omran, A. \& Foo, C. K. (2009). The potential effects of variation orders in Construction 
Projects. Journal of Engineering, 2, 141-152.

Palinkas, L. A., Horwitz, S. M., Green, C. A., Wisdom, J. P., Duan, N. \& Hoagwood, K. (2015). Purposeful sampling for qualitative data collection and analysis in mixed method implementation research.

Wu, C., Hsieh, T. \& Cheng, W. (2005). Statistical analysis of causes for design change in highway construction in Taiwan. International Journal of Project Management, Vol. 23, 554-563.

Yadeta, A. E. (2016) The Impact of Variation Order on Public Building Projects. Journal of Construction Engineering and Management, 5(3), 86-91.

Yin, R. K. (2009) Case Study Research: Design and Methods. 4th ed. London: SAGE Publications 